\title{
Briefing: The role of historical records in current and future civil engineering practice
}

Barry Goldsmith Clarke PhD, FGS, FICE

Professor, University of Leeds, Leeds, UK (b.g.clarke@leeds.ac.uk)

\section{Introduction}

Civil engineers design, build, operate, maintain and adapt projects with characteristics that distinguish them from other types of projects created by other engineering disciplines and artists.

- They transform people's lives by creating the infrastructure and built environment that underpins the wealth, health and well-being of society.

- They are complex systems that require a multidisciplinary approach.

- Most civil engineering projects are unique.

- They are geographically distributed and mostly stationary.

- There is a sense of permanence because they can last for one or more generations.

- They are adapted throughout their life to cope with political, social, economic and technological changes.

- They generate a wealth of information in the form of objects, letters, minutes, reports, papers, calculations, drawings, images and, now, digital records.

It is the wealth of information that is the subject of this paper and how relevant it is to current and future generations of engineers.

\section{Civil engineering projects}

The built environment, created through a series of political, social, economic and technical decisions, comprises the critical infrastructure of lifeline systems of energy, communications, transportation, waste disposal, water supply, social infrastructure of healthcare, education, retail, leisure, finance, domestic infrastructure and commercial and industrial facilities. The planning, design, construction, maintenance, operation and use of these infrastructure systems must be considered within the context of the natural environment and the society it supports in order to create resilient infrastructure that communities rely on - that is, the community and infrastructure must be robust with built-in redundancy that can be rapidly restored in a resourceful manner.

Therefore, records of civil engineering projects have a real value to practising engineers because of the longevity of civil engineering projects and the fact that during their life it is likely that they will be updated and/or adapted to cope with change of use, technological change, regulatory changes and, possibly, catastrophic events. Thus, practising engineers have a duty to engage in creating archival material and ensuring that it is relevant and of sufficient quality so that it is of value to future generations of engineers - for example
- factual and interpretative ground investigation reports

- design calculations including sources of data, design methodology and assumptions

- design of temporary works

- site records covering technical matters

- design and as-constructed drawings

- specifications, including those of proprietary materials

- photographs of the details of the construction

- reports and technical papers relating to the project.

\section{Archives and collections}

The wealth of information generated by a civil engineering project is a primary source of information that forms the archive related to that project (e.g. drawings, photographs, reports and other records for the Thames Tunnel, London, UK; the Forth Railway Bridge, Edinburgh, UK; and the Sydney Harbour Bridge, Sydney, Australia) (ICE, 2017). Archives can centre on a person (e.g. the Rennie Reports), an organisation (e.g. the Institution of Civil Engineers (ICE) Council minutes) or a project (ICE, 2017). Archives can exist in many places - personal records, companies, public authorities, professional and charitable organisations and national bodies - and the information related to a project may be distributed between different archives. Not all archives are publicly accessible (e.g. company and individual records); not all records are of value to the operation, maintenance and adaption of existing projects; and not all archives are registered.

Archives have a value and, because they are formed of primary information and cannot be replaced, they must be treated with great care. This is the responsibility of the archivists, a professional discipline represented in the UK by the Archives and Records Association (see ARA (2017)), which sets standards of professional conduct; maintains a professional register; provides, monitors and develops training; and promotes the exchange of expertise and experience.

The value of archives is often an opportunity to interpret and understand history; however, in civil engineering, the greatest value of these archives lies in the fact that they can be an essential source of information necessary to understand the performance of these complex projects, to adapt the projects to meet a change in their use, to contribute to the development of associated projects and, in extreme cases, to provide critical information for forensic investigations. 
The Archive Panel of the ICE defined archives as 'records adjudged worthy of permanent preservation for reference or research'. Thus, any record produced or received in the normal process of administration of any organisation may become an archive - that is, the records retained in an archive are a result of a process. The important items from a historical standpoint are probably the business archives such as articles of association, partnership agreements and accounts, and engineering archives such as engineers' reports, diaries and notebooks; drawings; photographs; calculations; estimates; contract documents; letter books and correspondence. While these are historical records, they are of immense value, particularly the engineering archives, to future generations both for use as references and for undertaking research.

- Civil engineering projects undergo planned and unplanned maintenance and, because of their longevity, will be adapted throughout their life (e.g. the Roman road network, the canals of the eighteenth century, the railways of the nineteenth century and the motorways of the twentieth century). The asconstructed drawings and design calculations - that is, the original records - are invaluable references to undertake these works.

- Civil engineering projects are unique and complex. Undertaking research into their performance is used to develop codes of practice and guidance notes for design and construction. This is increasingly important with the emergence of risk-based design to take account of the increased uncertainty because of changes in the environment and in technology; the pace of change is increasingly making current practice less relevant.

Records are also held in collections which have not come about as the result of a process. Collections can include original material. Records, whether held in archives or collections, can be interpreted to create a secondary source of essential information held in collections such as libraries. Both archives and collections are structured. Archives are a result of a process in which information is catalogued or listed according to its provenance or creator and any links between the items (e.g. the order in which they were stored by the creator) is, where possible, retained or reproduced so that the original filing system could be recreated. The reason for the significance of provenance it that it is this which confirms its credibility and hence reliability. Library books are arranged by subject or theme, and no one item has a connection to another.

The largest collections of civil engineering information are probably the ICE and American Society of Civil Engineers (ASCE) libraries. The ICE library (ICE, 2017) has the largest collection, with over 130000 titles, including major conference series, and over 900 periodical titles, as well as a growing e-book collection. The ASCE Library (2017) is the largest publisher of civil engineering titles (of which they have 38). The ICE and ASCE continue to expand their collections through their events teams and publishing arms, thus making their collections relevant to future generations.

In 2018, the ICE will celebrate 200 years, not as a reflection on what its members have achieved but as a celebration of the contribution its members have made to society in the past and continue to make in the present and, most importantly, the future. Civil engineering archives and collections provide a wealth of information to demonstrate that contribution and to deal with the infrastructure in order to cope with population growth, urbanisation, resource scarcity, technological changes and environmental changes - challenges that the civil engineering community face to deliver the lifelines society expects and depends on.

\section{The development of archives and collections}

Civil engineers have always existed and, despite the impact of artificial intelligence, are one of the few professions that will exist in the future. However, it was not until the eighteenth century that the modem concept of the civil engineer emerged. The eighteenth century is an important milestone in the development of civil engineering because that was the time across Europe that the role of civil engineers was recognised - for example, the Smeatonian Society (1771), École Nationale des Ponts et Chaussées (1747) and Technische Universität Carolo-Wilhelmina zu Braunschweig (1745). It was driven by a more politically stable environment and greater access to funds facilitating the development of transport to move people, resources and goods. Civil engineers made a significant contribution in what could be described as the first era of modern civil engineering, with land drainage, particularly of the fens, contributing to the agricultural revolution. John Grundy Sr (1696-1748) and John Grundy Jr (1719-1783) are examples of engineers who were engaged in this revolution, whose papers and drawings are part of the ICE's collections (ICE, 2017).

The next eras of civil engineering leading to increased trade and the first industrial revolution were the Turnpike Acts (1663-1836) and Canal Acts (1754-1884). Brindley (1716-1772), Smeaton (1724-1792), Telford (1757-1834) and Rennie (1761-1821) are examples of civil engineers associated with this period whose papers, drawings and reports are held within the ICE Archives (ICE, 2017). The Railway era (1771-1851) started with the wagonways in the coalfields and through the pioneering work of George Stephenson (1781-1848), Robert Stephenson (1803-1859) and Brunel (1806-1859), creating 10000 miles $(16093 \mathrm{~km})$ of railways between 1825 and 1860 , of which 9800 miles $(15771 \mathrm{~km})$ still exist today, demonstrating the importance of retaining information about the construction, maintenance and modification of the civil engineering projects.

While the eighteenth and nineteenth centuries were dominated by individuals, the records of their projects can be found in numerous archives. For example, records of the first UK canal, the Bridgewater canal, and the first UK railway, from Stockton to Darlington, are found in the National Archives (2017), university 
archives (Salford University, 2017) and local authority archives (Manchester City Council, 2017; North Yorkshire County Council, 2017). The National Archives lists 24249 records of civil engineering held by 243 organisations, but there are many other records and organisations not listed, demonstrating the difficulty of searching archives, hence the importance of collections.

\section{The role of archivists}

Archivists and librarians face the issues of identifying information of value, preservation, space and digitisation.

- Identifying information of value: From a historical standpoint, all information has value, but given the difficulties of space and preservation, not all information can be stored. It is possible to set criteria based on a person, a project or an organisation, but there could be other reasons, such as impact. However, in the case of civil engineering, project information should be stored for the lifetime of the project. After that, much of the information will be of historical interest but not necessarily of value to practising engineers.

v Preservation: The second challenge is the need to preserve important information. This includes setting policies, assessments, prioritisation systems, the allocation of resources and emergency and disaster planning, in addition to environmental control, maintenance and conservation, digitisation, preservation photocopying and microfilm.

- Digitisation: A solution to the cost and limit of space and, most importantly, in order to increase access is the digitisation of the existing information; new information is likely to be digital. Digitisation of physical records increases access but must not affect the original record and be of sufficient quality to replicate the original documents. Digital information is at risk of loss due to media (removable) decay/obsolescence, hardware obsolescence, software/data format obsolescence, online storage disaster/decay and incomplete/inadequate capture (Gollins, 2009).

\section{The role of civil engineers}

Given the wealth of information that is generated by civil engineering projects and the fact that those projects are likely to exist for one or more generations, civil engineers have a duty to future generations to create project archives. Examples of these are the distributed archives created by the Motorway Archive Trust (2017) to record the construction of the UK motorway network, the London Olympics Learning Legacy (see Olympic Delivery Authority (2017)) and the Crossrail Learning Legacy (see Crossrail Ltd (2017)). The first is an example of a distributed archive, mostly in county record offices, recording the construction of the motorway network since 1950; the last two are examples of a structured approach to collating and disseminating good practice, innovation and lessons learnt from these major projects, which has been facilitated by the Internet.

The London Olympics and Crossrail archives are examples of the new generation of digital archives. The projects represent only a small percentage of the $£ 100$ billion spent annually on construction projects in the UK, but their archives do provide a model to build project-based archives often created by companies and individuals. These archives have a historic value and, more importantly, value to future generations of civil engineers. The Crossrail Learning Legacy, based on the London Olympics Learning Legacy themes, was developed in consultation with the industry to create an industry standard for future learning legacies. There are 12 themes, covering project and programme management, procurement, authorisations and consents, land and property, health and safety, environment, engineering, operations, talent and resources, external affairs, innovation and information management and technology. Documents take the form of good practice documents, microreports, case studies, technical papers and research summaries.

The significant advantage of an electronic archive is that it can be accessed using a search engine and/or can be assembled within a framework to be catalogued. The latter has the advantage that some thought goes into creating the archive, thus increasing its value.

- Create a framework composed of themes, with each theme containing several topics. For example, the environmental theme of the Crossrail Learning Legacy contains topics covering environmental requirements, environmental management, air quality, biodiversity, resource management, energy efficiency and carbon dioxide, environmental design, environmental behaviours and incentives, noise and vibration and archaeology.

- Identify documents that fit the topics, noting that some documents may fit into more than one topic. It may be necessary to create a summary or research documents, although for smaller projects, this may not be feasible because of the time involved.

\section{Concluding remarks}

Archives have always had a value for practising civil engineers because of the life of the projects and the fact that they will be adapted and/or changed throughout their life. Therefore, civil engineers have a responsibility to future generations to create and maintain records of civil engineering projects. The switch from physical to virtual records has created an opportunity to make archives more accessible, of interest to the public and of great value to future generations.

Civil engineers also have a duty to society to continue their professional development throughout their career. This includes adding to the collection of civil engineering knowledge by submitting papers and reports of project case studies and civil engineering practice.

Engineering archives and collections are of value to future generations of civil engineers, which means that the current generation has a duty to create them. 
Briefing: The role of historical records in current and future civil engineering

practice

Clarke

\section{REFERENCES}

ARA (Archives and Records Association) (2017) http://www.archives.org.uk (accessed 18/03/2017).

ASCE Library (American Society of Civil Engineers) (2017) http:// ascelibrary.org/ (accessed 18/03/2017).

Crossrail Ltd (2017) http://learninglegacy.crossrail.co.uk/ (accessed 18/03/2017).

Gollins T (2009) Parsimonious preservation: preventing pointless processes. Online Information 2009 Proceedings, pp. 75-78. See http://www. nationalarchives.gov.uk/documents/information-management/parsimoniouspreservation.pdf (accessed 14/03/2017).

ICE (2017) ICE Library, Publishing and Digital Resources. ICE, London, UK. See https://www.ice.org.uk/disciplines-and-resources/ice-libraryand-digital-resources (accessed 14/03/2017).

Manchester City Council (2017) Archives and Local History. Manchester City Council, Manchester, UK. See http://www. manchester.gov.uk/info/448/archives and local history (accessed 14/ 03/2017).

Motorway Archive Trust (2017) http://www.ukmotorwayarchive.org/ (accessed 18/03/2017).

National Archives (2017) http://www.nationalarchives.gov.uk/ (accessed 18/03/2017).

North Yorkshire County Council (2017) County Record Office. North Yorkshire County Council, Northallerton, UK. See http://www. northyorks.gov.uk/article/23584/County-record-office (accessed 14/03/2017).

Olympic Delivery Authority (2017) http://learninglegacy.independent.gov. uk/ (accessed 18/03/2017).

Salford University (2017) Archives and Special Collections. Salford University, Salford, UK. See http://www.salford.ac.uk/library/archivesand-special-collections (accessed 14/03/2017).

\section{How can you contribute?}

To discuss this paper, please email up to 500 words to the editor at journals@ice.org.uk. Your contribution will be forwarded to the author(s) for a reply and, if considered appropriate by the editorial board, it will be published as discussion in a future issue of the journal.

Proceedings journals rely entirely on contributions from the civil engineering profession (and allied disciplines). Information about how to email your paper online is available at www.icevirtuallibrary.com/page/authors, where you will also find detailed author guidelines. 